\title{
D108
}

\section{天敵導入によるハウスピーマン栽培にみられる 作業者の皮虚障害について}

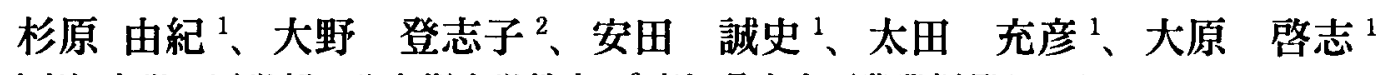
${ }^{1}$ 高知大学 医学部 公衆衛生学教室、 ${ }^{2}$ 高知県中央西農業振興センター

【はじめに】高知県でのピーマン、シシトウ類の栽 培様式はハウス促成栽培がほとんどで、定植は 8 9 月に行われ、収樓は $9 \sim 10$ 月から始まり翌年の 6 月 末まで約 10 ケ月間続く。その間多くの種類の害虫被 害が問題となるが、中でもミナミキイロアザミウマ の被害が最も大きい。殺虫剤の利用に変わるものと して、平成 13 年度から、アザミウマ類に対する天敵 タイリクヒメハナカメムシを利用する環境保全型農 業か蒪入されたが、タイリクヒメハナカメムシを入 れたハウス内での作業者に、皮膚の発赤、腫脹、か ゆみ等の症状が訴えられたため、天敵導入と作業者 の皮膚症状との関連を検討した。

【方法】1.皮唐症状の経験実態に関する賀問紙調査 天敵を導入したハウス内作業者の皮唐症状経験の実 態を調查するため、2003 年 5 ～6 月に自記式質問紙 調查を実施した。対象は高知県中央農業改良普及所 管内のピーマン部会に属する天敵導入農家全数 38 戸のハウス作業従事者 76 名である。男は 37 名、女 は39名であった。調查内容は、各作業者が収鍫作業 に従事した 2002 年 9 月 2003 年 5 月に経験した皮 膚症状の有無と、その皮膚症状を経験した暦月、症 状の持続期間、部位、対処方法、帽子や上衣、手袋 等保護具の着用の有無である。2.天敵発生量調查高 知県中央農業改良普及所の改良普及員が、タイリク ヒメハナカメムシの放飼後、収穫作業が行われた 2002 年 10 月 2003 年 5 月のほほ毎週、協力の得ら れた天敵導入農家 8 戸において、20 花あたりのタイ リクヒメハナカメムシの成虫、幼虫数量を調查した。 [結果】 八ウス内作業中、または作業後に皮唐症状 を経験した者は 76 名中 29 名 (38.2\%) であった。 症状経験率は、性別では男 $32.4 \%$ 、女 $43.6 \%$ と、有 意ではなかったが女に高かった。年齢階級別には 49 歳以下 $56.5 \% 、 50$ 歳代 $44.4 \% 、 60$ 歳代 $27.3 \% 、 70$
歳以上 $15.4 \%$ と年齢が低いものの方が症状経験率は 高かった。作目別では、ピーマン $31.8 \%$ 、シシトウ 38.5\%と、有意ではなかったがシシトウが滈かった。 症状を経験した 29 名について、訴えが最も多かった 症状はかゆみであり、症状経験者の $68.9 \%$ であった。 かゆみのみは $24.1 \%$ 、発赤を伴うかゆみは $24.1 \%$ 、

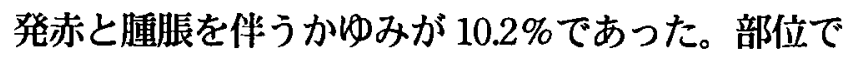
は形部が $55.3 \%$ 、上腕および手部・手首がそれぞれ $27.5 \%$ 、前腕が $20.7 \%$ でった。腹部、胸部など露出 部位以外の症状も $30.9 \%$ 認められた。症状の持続期

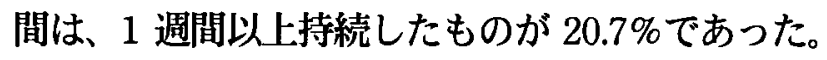
暦月別に計測した 76 名中の症状経験率と同じ期間 中の週別 100 花あたりのタイリクヒメハナカメムシ の虫数量の関係では、症状は 2 月頃から漸增し、3 ～5 月が最も多くなった。タイリクヒメハナカメム シ数には 11〜12 月頃に小さなピーク、3〜5 月頃に 大きなピークが認められた。3〜5月のタイリクヒメ ハナカメムシ薮量の大きなピークと $3 \sim 5$ 月の症 状経験率の上昇とはほほ一致していた。

[考察]作物害虫に対する天敵の利用は環境保全型 農業の柱であるが、天敵蜘量が一定以上になると かゆみを伴う刺されが発生しており、天敵導入時に は注意が必要である。 